\title{
Antibiofilm activity of glycolic plant extracts on Klebsiella pneumoniae clinical
}

\section{isolates}

\author{
Atividade antibiofilme de extratos glicólicos de plantas em isolados clínicos de Klebsiella \\ pneumoniae
}

Actividad antibiofilm de extractos glicólicos de plantas en aislados clínicos de Klebsiella pneumoniae

Lucas de Paula Ramos

ORCID: https://orcid.org/0000-0002-2682-2796

São Paulo State University, Brazil E-mail: lucas93paula@hotmail.com.br

Thaís Cristine Pereira

ORCID: https://orcid.org/0000-0002-7206-3348

São Paulo State University, Brazil

E-mail: thais.pereira@unesp.br

Marcela dos Santos Oliveira

ORCID: https://orcid.org/0000-0003-2727-2949

São Paulo State University, Brazil

E-mail: ma_soliveira@hotmail.com

Maria Angélica de Sá Assis

ORCID: https://orcid.org/0000-0002-0145-9687

São Paulo State University, Brazil

E-mail: maassis@gmail.com

Suelen Simões Amaral

ORCID: https://orcid.org/0000-0003-0652-9127

São Paulo State University, Brazil

E-mail: suelensimoes@live.com

Leandro Wagner Figueira

ORCID: https://orcid.org/0000-0002-8504-2183

São Paulo State University, Brazil

E-mail: leandrowf@live.com

Amanda Romangnoli

ORCID: https://orcid.org/0000-0001-7234-5022

São Paulo State University, Brazil

E-mail: amandarb.1708@gmail.com

Felipe Eduardo Oliveira

ORCID: https://orcid.org/0000-0003-3026-646X

São Paulo State University, Brazil

E-mail: felipe.eoliveira@ymail.com.br

Carlos Eduardo Rocha Santos

ORCID: https://orcid.org/0000-0001-6592-0244

São Paulo State University, Brazi

E-mail: carloseduardorochasantos@yahoo.com.br

João Manoel Theotônio dos Santos

ORCID: https://orcid.org/0000-0003-2822-0737

Anhembi Morumbi University, Brazil

E-mail: joao.theotonio@cardiovale.com.br

Patrícia Michelle Nagai de Lima

ORCID: https://orcid.org/0000-0001-7870-0005

São Paulo State University, Brazil

E-mail: patrícia.nagai@unesp.br

Luciane Dias de Oliveira

ORCID: https://orcid.org/0000-0002-5465-9551

São Paulo State University, Brazil

E-mail: luciane.oliveira@unesp.br

\begin{abstract}
Objective: Evaluate the anti-biofilm activity of Gymnema sylvestre, Hamamelis virginiana, Juglans regia, Persea americana, Pfaffia paniculata, Rosmarinus officinalis, Stryphnodendron barbatiman and Thymus vulgaris extracts in 3 MDR strains and 1 ATCC (4352) of Klebsiella pneumoniae. Methods: First were made a screening with broth microdilution test, protocol M7-A9, according to CLSI. Extracts that presented values for Minimal Microbicidal
\end{abstract}


Concentration (MMC) were selected for biofilms tests on 96 wells plates. Treatments used concentrations of 25 and $50 \mathrm{mg} / \mathrm{mL}$, after biofilms were measured by biomass and MTT tests and statistically analyzed by ANOVA and Tukey test ( $\mathrm{p}$ 0.05). Results: All extracts showed MIC for all K. pneumoniae strains studied, with values ranging from 12.5$100 \mathrm{mg} / \mathrm{mL}$. Biomass of the strains ATCC and MDR strain (400381) of K. pneumoniae obtained reductions of 37.7 and $44.3 \%$ with $P$. paniculata and $R$. officinalis extracts. The isolate 386546 obtained a reduction of $29.7 \%(\mathrm{p}<0.05)$ under $R$. officinalis action. Conclusion: Among the extracts studied, those that were most effective in the anti-biofilm action were $J$. regia, P. paniculata and $R$. officinalis. Therefore, these extracts could act as bactericidal agents against K. pneumoniae MDR.

Keywords: Klebsiella pneumoniae; Anti-biofilm; Phytotherapy; Bacteria; Resistance; Microbiology.

\title{
Resumo
}

Objetivo: Avaliar a atividade antibiofilme dos extratos de Gymnema sylvestre, Hamamelis virginiana, Juglans regia, Persea americana, Pfaffia paniculata, Rosmarinus officinalis, Stryphnodendron barbatiman e Thymus vulgaris em 3 cepas clínicas e 1 ATCC (4352) de Klebsiella pneumoniae. Métodos: Primeiramente foi feita uma triagem com teste de microdiluição em caldo, protocolo M7-A9, conforme CLSI. Os extratos que apresentaram valores de Concentração Microbicida Mínima (CMM) foram selecionados para testes de biofilmes em placas de 96 poços. Os tratamentos utilizaram concentrações de 25 e $50 \mathrm{mg} / \mathrm{mL}$, após os biofilmes foram mensurados pelos testes de biomassa (Cristal violeta) e MTT, e analisados estatisticamente por ANOVA e teste de Tukey ( $\mathrm{p}<0,05)$. Resultados: Todos os extratos apresentaram CIM para todas as cepas de K. pneumoniae estudadas, com valores variando de $12,5-100 \mathrm{mg} / \mathrm{mL}$. A biomassa das cepas ATCC e MDR (400381) de K. pneumoniae obteve reduções de 37,7 e 44,3\% com os extratos de $P$. paniculata e $R$. officinalis. O isolado 386546 obteve redução de $29,7 \%$ (p <0,05) sob ação de $R$. officinalis. Conclusão: Dentre os extratos estudados, os mais eficazes na ação anti-biofilme foram $J$. regia, $P$. paniculata e $R$. officinalis. Portanto, esses extratos poderiam atuar como agentes bactericidas contra K. pneumoniae MDR.

Palavras-chave: Klebsiella pneumoniae; Antibiofilme; Fitoterapia; Bactéria; Resistência; Microbiologia.

\begin{abstract}
Resumen
Objetivo: Evaluar la actividad anti-biofilm de extractos de Gymnema sylvestre, Hamamelis virginiana, Juglans regia, Persea americana, Pfaffia paniculata, Rosmarinus officinalis, Stryphnodendron barbatiman y Thymus vulgaris en 3 cepas MDR y 1 ATCC (4352) de Klebsiella pneumoniae. Métodos: Primero se realizó un cribado con caldo de prueba de microdilución, protocolo M7-A9, según CLSI. Los extractos que presentaban valores para la concentración microbicida mínima (CMM) se seleccionaron para las pruebas de biopelículas en placas de 96 pocillos. Los tratamientos utilizaron concentraciones de 25 y $50 \mathrm{mg} / \mathrm{mL}$, luego de que se midieran las biopelículas mediante pruebas de biomassa (cristal violeta) y MTT, y se analizaran estadísticamente mediante ANOVA y prueba de Tukey (p<0.05). Resultados: Todos los extractos mostraron CMM para todas las cepas de K. pneumoniae estudiadas, con valores que variaron de 12.5-100 mg/mL. La biomasa de las cepas ATCC y MDR (400381) de K. pneumoniae obtuvo reducciones de 37,7 y 44,3\% con extractos de P. paniculata y R. officinalis. El aislado 386546 obtuvo una reducción del 29,7\% (p $<0,05)$ bajo la acción de $R$. officinalis. Conclusión: Entre los extractos estudiados, los más eficaces en la acción antibiofilm fueron $J$. regia, $P$. paniculata y $R$. officinalis. Por tanto, estos extractos podrían actuar como agentes bactericidas frente a $K$. pneumoniae MDR.
\end{abstract}

Palabras clave: Klebsiella pneumoniae; Antibiofilm; Fitoterapia; Bacteria; Resistencia; Microbiología.

\section{Introduction}

Klebsiella pneumoniae is a Gram-negative bacillus in the family of enterobacteria. It is an opportunistic pathogen, present in $70 \%$ of hospital infections, and causes mainly pulmonary and urinary tract infections (Bowers et al., 2016; Rahim et al., 2016). K. pneumoniae may be prevalent as an infectious agent in patients with urinary catheters and may develop bacterial biofilms in these devices (Djeribi, Bouchloukh, Jouenne, \& Menaa, 2012; Ramstedt et al., 2019). This virulence mechanism is fundamental in many bacterial infections, as it can resist the host's defense system and antimicrobial treatments (Djeribi et al., 2012; Vuotto, Longo, Balice, Donelli, \& Varaldo, 2014). In addition to the ability to form biofilms, the species has other virulence factors, such as polysaccharide capsules, siderophore, urease, the presence of fimbriae and resistance to antibiotics, in which they help in the maintenance and resistance of infections (Bowers et al., 2016; Clegg \& Murphy, 2016; Rahim et al., 2016).

Several classes of antimicrobials are commonly used to treat infections caused by $K$. pneumoniae, but excessive and inappropriate use can favor the increase in microbial resistance (Aslam et al., 2018; Goossens, 2009; Osman, Hassan, Orabi, \& Abdelhafez, 2014). In hospital settings, where the use of these drugs is frequent, multidrug-resistant (MDR) bacteria have been a problem (Aslam et al., 2018). K. pneumoniae has an easier time developing resistance when compared to other bacteria. 
Resistance to most conventional antibiotics is due to the emergence of strains producing broad-spectrum $\beta$-lactamase (ESBL) and carbapenemase producers (Cai et al., 2012). In view of this, the World Health Organization (WHO) declared in 2017 that $K$. pneumoniae is among the critical resistant bacteria that need research to develop new treatment alternatives (WHO, 2017). The consequences of antimicrobial resistance caused by $K$. pneumoniae are serious and can lead to increased morbidity, mortality or even longer hospital stays. The growth of MDR bacteria limits and makes therapeutic options more and more difficult, thus emerging the need to search for new drug alternatives (Li \& Webster, 2018; Pacios et al., 2020).

Among the therapies studied, for the control of resistant strains, phytotherapy gained notability. It is known that medicinal plants are rich in phytochemicals with diverse biological activities. Many studies have demonstrated the antimicrobial action of different plant extracts against bacteria and fungi (de Oliveira et al., 2017; De Zoysa, Rathnayake, Hewawasam, \& Wijayaratne, 2019; Elansary et al., 2018; Hadadi, Nematzadeh, \& Ghahari, 2020). However, there are still many gaps, whether due to plant species or even the use of extracts against MDR strains (Farooqui et al., 2015; Khalil, Fikry, \& Salama, 2020). Considering the world scenario of microbial resistance and the wide variety of plant extracts with potential to be explored, the present study evaluated the antimicrobial action of Gymnema sylvestre (Gimena), Hamamelis vir-giniana L. (Hamamelis), Juglans regia L. (Walnut), Persea americana (Avocado), Pfaffia paniculata (Brazilian Ginseng), Rosmarinus officinalis L. (Rosemary), Stryphnodendron barbatiman (Barbatiman) and Thymus vulgaris (Thyme) in planktonic forms and biofilms of Klebsiella pneumoniae MDR strains.

\section{Methodology}

\subsection{Extracts}

Glycolic extracts of Gymnema sylvestre (Gimena), Hamamelis virginiana L. (Hamamelis), Juglans regia L. (Walnut), Persea americana (Avocado), Pfaffia paniculata (Brazilian Ginseng), Rosmarinus officinalis L. (Rosemary), Stryphnodendron barbatiman (Barbatiman) and Thymus vulgaris (Thyme) were purchased from Mapric (SP, Brazil) at a concentration of 200 $\mathrm{mg} / \mathrm{mL}(20 \%)$, eluted in propyleneglycol.

\subsection{K. pneumoniae ATCC and multidrug-resistant strains}

Antibacterial activity was tested on four K. pneumoniae strains, one ATCC 4352 strain (ATCC - American Type Culture Collection) and three MDR strains (367725, 386546, 400381) provided by Bioclin Laboratory, belonging to Policlin medical group - São José dos Campos, São Paulo, Brazil. The resistance of clinical isolates was identified using the autoSCAN 4 automated system (Beckman Coulter, Brea, CA, USA) (Delgado-Gardea et al., 2016). The resistance profile of clinical isolates is shown in Appendice - Table A1.

\subsection{Glycolic extracts MIC and MMC}

MIC (Minimum Inhibitory Concentration) and MMC (Minimum Microbicidal Concentration) values of the extracts were determined by Broth Microdilution Method, protocol M7-A9 (2012), according to CLSI. First, suspensions of K. pneumoniae strains were prepared in sterile saline solution $(\mathrm{NaCl} 0.9 \%)$ and turbidity was adjusted to $10^{6} \mathrm{CFU} / \mathrm{mL}$ in a spectrophotometer (Micronal, São Paulo, Brazil). The test was performed in 96-well plates (TPP, Trasadingen, Switzerland), where each extract was serially diluted in 10 wells with $100 \mu \mathrm{L} /$ well of Muller Hilton Broth (Himedia, Mumbai, India), obtaining concentrations from 100 to $0.19 \mathrm{mg} / \mathrm{mL}$. Next, $100 \mu \mathrm{L}$ of standardized microorganism suspension was added to all the wells and the plate was incubated in at $37^{\circ} \mathrm{C}$ for $24 \mathrm{~h}$. After, MIC was determined in the last well of the microplate where no turbidity was observed. For MMC determination, aliquots were removed from the microplates and seeded on Brain Heart Infusion (BHI) agar (Himedia, Mumbai, India) and were determined in the lowest concentration where no growth of colonies was observed. 


\subsection{Antimicrobial action against monotypic biofilms}

After the screening promoted by the broth microdilution test, only the extracts that obtained MMC into the interval tested were selected for monotypic biofilm tests: H. virginiana, J. regia, P. americana, P. paniculata, and R. officinalis.

Initially, the K. pneumoniae strains were cultured in BHI broth (Himedia, Mumbai, India) at $37^{\circ} \mathrm{C} / 24 \mathrm{~h}$. After incubation, the microorganism suspension was centrifuged at $2000 \mathrm{rpm} / 10 \mathrm{~min}$ (MPW-350, Warsaw, Poland) and washed twice with $0.9 \%$ saline solution for the removal of the microorganisms metabolites. The turbidity of the suspensions was adjusted in a spectrophotometer (Micronal) at a concentration of $10^{7} \mathrm{CFU} / \mathrm{mL}$. The microorganism suspension was distributed into 96-well plates with $\mathrm{N}=10$ for each group, then $100 \mu \mathrm{L} /$ well of BHI broth (Himedia, Mumbai, India) was added and the plate was incubated at $37^{\circ} \mathrm{C}$ for $48 \mathrm{~h}$, under constant stirring $(75 \mathrm{rpm})$.

\subsection{Treatment}

In the control group, $200 \mu \mathrm{L} /$ well of $0.9 \%$ saline was applied and in the experimental groups, $200 \mu \mathrm{L} /$ well of each extract (H. virginiana, J. regia, P. americana, P. paniculata, and $R$. officinalis) at concentrations of 25 and $50 \mathrm{mg} / \mathrm{mL}$ were applied, with 10 replicates for each group. After $5 \mathrm{~min}$ of treatment, the extracts were removed and the wells were washed twice with $0.9 \%$ saline solution. In order to evaluate the action of the extracts on the biofilm, the following tests were performed: measurement of the biomass by violet crystal and evaluation of the metabolic activity of the microorganisms by MTT (3- (4,5Dimethylthiazol-2- yl) -2,5-Diphenyltetrazolium bromide.

\subsection{Measurement of biomass by the Crystal violet test}

After the treatments, $200 \mu \mathrm{L} /$ well of methanol were added and after $20 \mathrm{~min}$, for biofilm fixation, it was removed and the plate was incubated at $37^{\circ} \mathrm{C}$ for $24 \mathrm{~h}$ for drying. After incubation, $200 \mu \mathrm{L} /$ well of violet crystal $1 \%(\mathrm{~V} / \mathrm{V}$ ) were added for 5 min and then the dye was removed and the wells washed twice with acetic acid 33\% (Synth, Diadema, Brazil) and sterile saline solution $(0.9 \% \mathrm{NaCl})$. The plate was read at $570 \mathrm{~nm}$ by the microplate reader (Lonza Biotek ELX808LBS, Winooski, Vermont) and the optical densities were converted into biofilm biomass (Skogman et al., 2012; Marcos-Zambrano et al., 2014).

\subsection{Metabolic activity evaluation}

Two hundred microliters of MTT (3- (4,5-Dimethylthiazol-2-yl) -2,5-Diphenyltetrazolium Bromide) solution were added to each well of the plate. The plate was incubated, protected from light, for $1 \mathrm{~h}$ at $37^{\circ} \mathrm{C}$. The solution was removed and $200 \mu \mathrm{L}$ of dimethylsulfoxide (DMSO) was added to the plate, which was incubated again, at $37{ }^{\circ} \mathrm{C}$ for $10 \mathrm{~min}$ and then placed in the shaker under constant shaking for another $10 \mathrm{~min}$. After this process, the optical densities were read in a microplate reader at $570 \mathrm{~nm}$ and converted into a percentage of metabolic activity of the microbial cells.

\subsection{Statistical analysis}

Data were statistically analyzed by ANOVA, complemented by the Tukey test, in order to verify the differences among the groups with $\mathrm{p}<0.05$, with GraphPad Prism 5.0 software

\section{Results}

All extracts showed MIC for all K. pneumoniae strains studied, at different concentrations (table 1). For K. pneumoniae ATCC 4352, H. virginiana obtained growth inhibition with $12.5 \mathrm{mg} / \mathrm{mL}, P$. americana and $R$. officinalis with $25 \mathrm{mg} / \mathrm{mL}, P$. paniculata with $50 \mathrm{mg} / \mathrm{mL}$ and S. barbatiman, G. sylvestre, J. regia, and T. vulgaris with $100 \mathrm{mg} / \mathrm{mL}$ (Table 1). For KPC 367725 
strain, the MIC of G. sylvestre, J. regia, S. barbatiman and T. vulgaris extracts obtained was $100 \mathrm{mg} / \mathrm{mL}, H$. virginiana, $P$. americana, and $R$. officinalis showed inhibition with $25 \mathrm{mg} / \mathrm{mL}$ and $P$. paniculata with $50 \mathrm{mg} / \mathrm{mL}$.

For KPC strain 386546, H. virginiana showed MIC with $12.5 \mathrm{mg} / \mathrm{mL}$, J. regia, $P$. americana, P. paniculata, and $R$. officinalis with $25 \mathrm{mg} / \mathrm{mL}$, S. barbatiman, and T. vulgaris with $50 \mathrm{mg} / \mathrm{mL}$ and G. sylvestre with $100 \mathrm{mg} / \mathrm{mL}$. KPC $400381 \mathrm{strain}$ was inhibited by $H$. virginiana with $12.5 \mathrm{mg} / \mathrm{mL}, J$. regia, P. americana and R. officinalis with $25 \mathrm{mg} / \mathrm{mL}, G$. sylvestre, J. regia and S. barbatiman with $50 \mathrm{mg} / \mathrm{mL}$ and T. vulgaris with $100 \mathrm{mg} / \mathrm{mL}$.

Regarding the microbicidal activity, G. sylvestre, S. barbatiman, and T. vulgaris extracts did not present MMC values for any strain of K. pneumoniae and the J. regia showed only two microbicidal actions (ATCC 4352 and KPC 367725 ) of the four strains analyzed. On the other hand, $H$. virginiana, $P$. americana, P. paniculata, and $R$. officinalis extracts were able to eliminate all strains, in different concentrations (Table 1).

For the ATCC 4352 strain, H. virginiana and $R$. officinalis extracts obtained MMC with $50 \mathrm{mg} / \mathrm{mL}, P$. americana extract with $25 \mathrm{mg} / \mathrm{mL}$ and $P$. paniculata with $100 \mathrm{mg} / \mathrm{mL}$. For strain 367725, H. virginiana, P americana, and R. officinalis extracts presented MMC with $50 \mathrm{mg} / \mathrm{mL}$ and P. paniculata extract with $100 \mathrm{mg} / \mathrm{mL}$. For strain 386546, H. virginiana obtained MMC with $12.5 \mathrm{mg} / \mathrm{mL}$, J. regia, P. americana and $R$. officinalis with $25 \mathrm{mg} / \mathrm{mL}$ and $P$. paniculata with $100 \mathrm{mg} / \mathrm{mL}$. For strain 400381, J. regia, P. americana, and $R$. officinalis extracts showed microbicidal activity with $25 \mathrm{mg} / \mathrm{mL}, H$. virginiana with 50 $\mathrm{mg} / \mathrm{mL}$ extract and $P$. paniculata with $100 \mathrm{mg} / \mathrm{mL}$.

With the screening promoted by the broth microdilution test, it was defined that extracts with MMC for all $K$. pneumoniae strains would be selected for biofilm tests. The concentrations of the extracts applied in monotypic biofilms also derived from the results of the broth microdilution test.

Table 1: Broth microdilution test performed with Klebsiella pneumoniae strains.

\begin{tabular}{|c|c|c|c|c|c|c|c|c|}
\hline \multirow[b]{2}{*}{ Glycolic extracts } & \multicolumn{2}{|c|}{ ATCC 4352} & \multicolumn{2}{|c|}{ KPC 367725} & \multicolumn{2}{|c|}{ KPC 386546} & \multicolumn{2}{|c|}{ КРC 400381} \\
\hline & MIC & MMC & MIC & MMC & MIC & MMC & MIC & MMC \\
\hline G. sylvestre (gimena) & 100 & Abs & 100 & abs & 100 & abs & 50 & abs \\
\hline $\begin{array}{l}\text { H. virginiana L. (witch } \\
\text { hazel) }\end{array}$ & 12,5 & 50 & 25 & 50 & 12,5 & 12,5 & 12,5 & 50 \\
\hline J. regia L. (walnut) & 100 & Abs & 100 & abs & 25 & 25 & 25 & 25 \\
\hline P. americana (avocado) & 25 & 25 & 25 & 50 & 25 & 25 & 25 & 25 \\
\hline $\begin{array}{l}\text { P. paniculata (brazilian } \\
\text { ginseng) }\end{array}$ & 50 & 100 & 50 & 100 & 25 & 100 & 50 & 100 \\
\hline $\begin{array}{l}\text { R. officinalis } L \text {. } \\
\text { (rosemary) }\end{array}$ & 25 & 50 & 25 & 50 & 25 & 25 & 25 & 25 \\
\hline $\begin{array}{l}\text { S. barbatiman } \\
\text { (barbatiman) }\end{array}$ & 100 & Abs & 100 & abs & 50 & abs & 50 & abs \\
\hline T. vulgaris (thyme) & 100 & Abs & 100 & abs & 50 & abs & 100 & abs \\
\hline
\end{tabular}


Legends: values express in $\mathrm{mg} / \mathrm{mL}$; Abs - Absent; MIC - Minimum Inhibitory Concentration; MMC - Minimum Microbicidal Concentration; absent - No values for MMC were found.

Source: Autors.

\subsection{Biomass reduction}

For the ATCC strain, only the P. paniculata and $R$. officinalis extracts presented statistically significant reductions ( $\mathrm{p}<0.05$ ) when compared to the control. For P. paniculata at 25 and $50 \mathrm{mg} / \mathrm{mL}$ there were reductions of $35.9 \%$ and $37.7 \%$, respectively, and for $R$. officinalis at $25 \mathrm{mg} / \mathrm{mL}$ and $50 \mathrm{mg} / \mathrm{mL}$, the reductions were 38.8 and $44.3 \%$, respectively (Figure 1).

The five extracts tested in the clinical strain 400381 obtained statistically significant reductions $(\mathrm{p}<0.05)$ compared to the growth of the control group. P. americana extract obtained reductions of $26.8(25 \mathrm{mg} / \mathrm{mL}) \mathrm{and} 28.8 \%(50 \mathrm{mg} / \mathrm{mL}), H$. virginiana of $41.5(25 \mathrm{mg} / \mathrm{mL})$ and $45.1 \%(50 \mathrm{mg} / \mathrm{mL}) \quad$, J. regia of $33.8(25 \mathrm{mg} / \mathrm{mL})$ and $39.7 \%(50 \mathrm{mg} / \mathrm{mL})$, P. paniculata of $42.7(25 \mathrm{mg} / \mathrm{mL})$ and $50 \%(50 \mathrm{mg} / \mathrm{mL})$. R. officinalis extract promoted the greatest reductions $(\mathrm{p}<0.05), 50.4(25 \mathrm{mg} / \mathrm{mL})$ and $50.5 \%(50 \mathrm{mg} / \mathrm{mL})$ (Figure 1$)$.

For KPC strain 386546, only the extract of $R$. officinalis presented statistically significant reductions $(\mathrm{p}<0.05)$ of the biomass, compared to the control group. These reductions were $29.8 \%$ for the concentration of $25 \mathrm{mg} / \mathrm{mL}$ and $29.7 \%$ for 50 $\mathrm{g} / \mathrm{mL}$. For the strain KPC 367725 , no extract showed a statistically significant reduction of the biomass $(\mathrm{p}<0.05)($ Figure 1$)$.

Figure 1 - Biomass reduction after extracts action on Klebsiella pneumoniae strains.
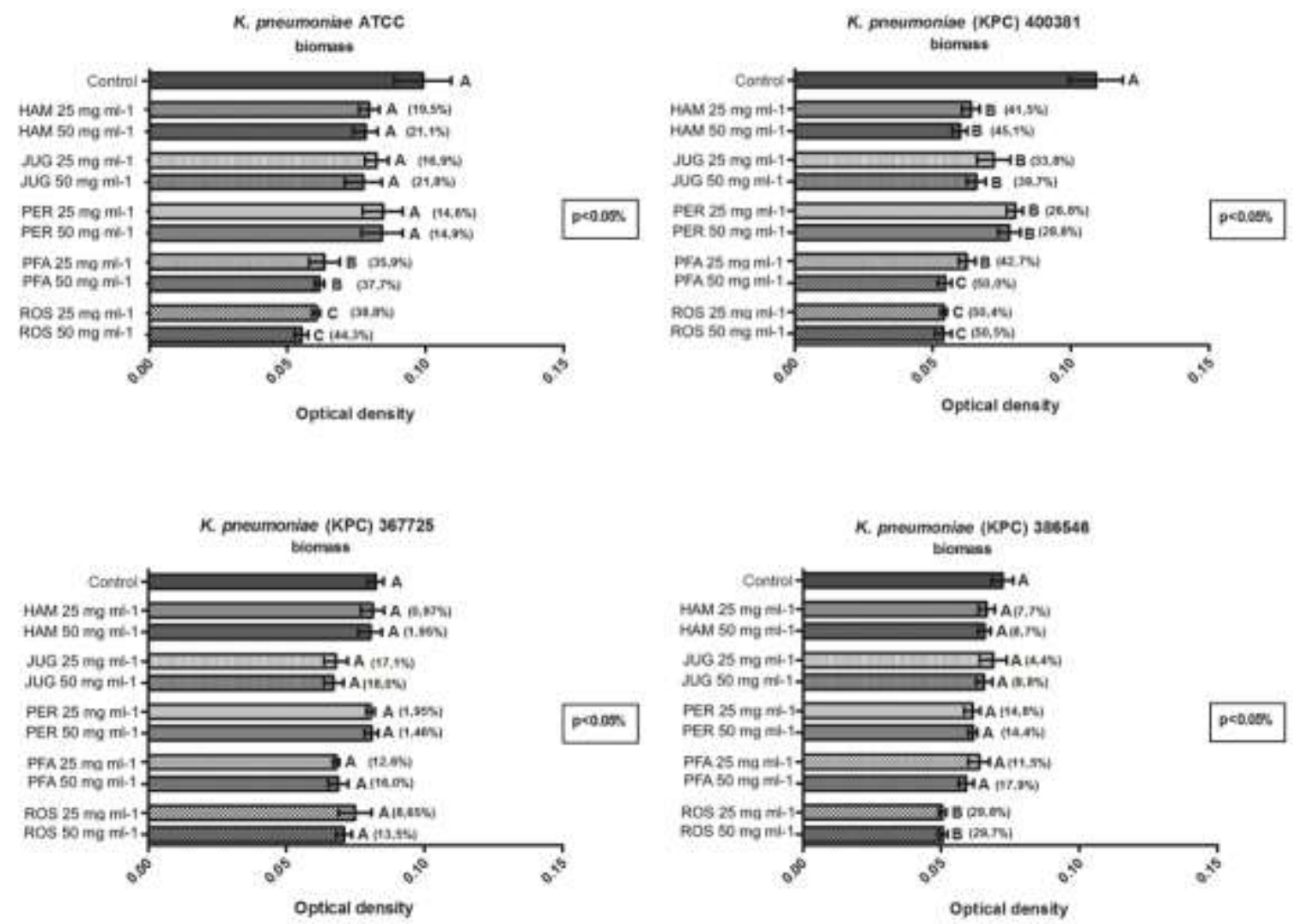

Legend: HAM- Glycolic extract of Hamamelis virginiana; JUG - Juglans regia glycolic extract; PER - Glycolic extract of Persea americana; PFA - Glycolic extract of Pfaffia paniculate; ROS - Glycolic extract of Rosmarinus officinalis. Different letters (A, B and C) indicate statistical significant difference (ANOVA, Tukey, p<0.05). K.pneumoniae ATCC ( $\mathrm{p}=0.0001)$; KPC $400381(\mathrm{p}=0.0001)$; KPC 367725 ( $\mathrm{p}=0.0018) ; \mathrm{KPC}$ $386546(\mathrm{p}=0.0001)$.

Source: Authors. 


\subsection{Reduction of metabolic activity of strains}

For K. pneumoniae ATCC strain, J. regia promoted the greatest reductions in the metabolic activity: $53.2 \%$ at $25 \mathrm{mg} / \mathrm{mL}$ and $41.3 \%$ at $50 \mathrm{mg} / \mathrm{mL}$, statistically different from other groups $(\mathrm{p}<0.05)$. R. officinalis and P. paniculata extracts also showed significant reductions when compared to the control ( $\mathrm{p}<0.05$ ): 30.3 and $39.7 \%$ for $R$. officinalis and 27.7 and $33.5 \%$ for $P$. paniculata. Only $P$. americana extract at $25 \mathrm{mg} / \mathrm{mL}$ and $H$. virginiana extract at 25 and $50 \mathrm{mg} / \mathrm{mL}$ did not present statistical significant reduction $(\mathrm{p}<0.05)$ in metabolic activity.

Regarding KPC 367725, all 5 extracts showed a significant reduction in metabolic activity. The extracts of $R$. officinalis (25 and $50 \mathrm{mg} / \mathrm{mL}), P$. paniculata $(25 \mathrm{mg} / \mathrm{mL})$ and $P$. americana $(50 \mathrm{mg} / \mathrm{mL})$ showed the greatest reductions. They were statistically similar to each other $(\mathrm{p}<0.05)$ but different from the control group $(\mathrm{p}<0.05)$. For the KPC strain 386546, only extracts of $J$. regia (25 and $50 \mathrm{mg} / \mathrm{mL}), H$. virginiana $(50 \mathrm{mg} / \mathrm{mL})$ and $R$. officinalis $(50 \mathrm{mg} / \mathrm{mL})$ showed a statistically significant reduction in metabolic activity $(\mathrm{p}<0.05)$. For KPC 400381 strain, only extracts of $R$. officinalis and J. regia, both at $50 \mathrm{mg} / \mathrm{mL}$ presented a statistically significant reduction when compared to the control group $(\mathrm{p}<0.05)$ (Figure 2).

Figure 2 - Metabolic activity reduction after extracts action on strains of Klebsiella pneumoniae.


Legend: HAM- Glycolic extract of Hamamelis virginiana; JUG - Glycolic extract of Juglans regia; PER - Glycolic extract of Persea americana; PFA - Glycolic extract of Pfaffia paniculata; ROS - Glycolic extract of Rosmarinus officinalis. Different letters (A, B and C) indicate statistical significant difference (ANOVA, Tukey, p<0.05). K.pneumoniae ATCC (p=0.0001); KPC 400381 (p=0.0001); KPC 367725 $(\mathrm{p}=0.0001)$; KPC $386546(\mathrm{p}=0.0001)$.

Source: Authors.

\section{Discusssion}

Bacterial resistance to conventional antimicrobials increases progressively, representing a global threat (Roca et al., 2015). The emergence of MDR pathogens searches for new treatment alternatives essential (Li \& Webster, 2018; Pacios et al., 
2020). Therefore, phytotherapy has been studied for its antimicrobial action, as it produces several bioactive compounds with therapeutic properties and has shown promising results against MDR bacteria (Assis et al., 2018; Elisha, Botha, McGaw, \& Eloff, 2017; Gadisa et al., 2019). Based on the above, this study evaluated the antimicrobial activity of Gymnema sylvestre, Hamamelis virginiana, Juglans regia, Persea americana, Pfaffia paniculata, Rosmarinus officinalis, Stryphnodendron barbatiman and Thymus vulgaris against multidrug resistance strains Klebsiella pneumoniae.

In this study, G. sylvestre glycolic obtained MIC at $100 \mathrm{mg} / \mathrm{mL}$ in K. pneumoniae ATCC and two clinical strains, but no MMC value was found, indicating a low antimicrobial potential. Corroborating with our results, Selvi et al. (2007) used the agar diffusion test and found the low antimicrobial activity of G. sylvestre in K. pneumoniae (Selvi, Devi, Chinnaswamy, Giji, $\&$ Sharmila, 2007). The ethanolic extract indicated moderate inhibition of the mentioned species and the aqueous extract showed no inhibition. The absence of antimicrobial activity of the aqueous extract of G. sylvestre against K. pneumoniae (MTCC 530) was also observed by Arora and Sood et al. (2017), in which they found that the strain was insensitive even when tested at a concentration of $30 \%$ of the extract (Arora \& Sood, 2017).

In relation to the Barbatiman extract (Stryphnodendron barbatiman, S. adstringens or S. obovatum), there are few reports in the literature that have evaluated its antimicrobial action. Ishida et al. (2009) reported the antifungal action of the extract on Cryptococcus neoformans (Ishida, Rozental, de Mello, \& Nakamura, 2009). The action of Barbatiman extract was also demonstrated against common microorganisms of the oral microbiota, in this study Pereira et al. (2011) observed that the mentioned extract can be an adjunctive method of prophylaxis and treatment of oral infectious conditions of the oral cavity (E. M. Pereira et al., 2011). De Freitas et al. (2018) reported that tannins obtained from the stem bark of the species have the potential for topical treatment of vaginal candidiasis and suggest that it may be an alternative for the treatment of infections caused by Candida spp. resistant to antifungals (de Freitas et al., 2018). Studies in the literature involving Barbatiman extract and microorganisms are scarce, and so far no reports of their action on $K$. pneumoniae strains have been found. Thus, the present study is a pioneer in the identification of antimicrobial activity against the growth of this species, thus, our findings demonstrate MIC of 50-100 mg/mL, showing that this extract can be a promising alternative against standard strains and K. pneumoniae MDR.

Fournomiti et al. (2015) assessed the antimicrobial action of Thymus vulgaris essential oil on clinical strains of $K$. pneumoniae and the results showed mean MIC values of $11.34 \mathrm{mg} / \mathrm{mL}$, being different from the results of the present study in which clinical strains of K pneumoniae were inhibited with $50 \mathrm{mg} / \mathrm{mL}$ and the ATCC strain with $100 \mathrm{mg} / \mathrm{mL}$ (Fournomiti et al., 2015). However, in the present study, the glycolic extract was used, which has advantages in relation to the water solubility of the extract, when compared to essential oil. On the other hand, our results are consistent with the study by Van Vuuren et al. (2009), who evaluated the essential oil of T. vulgaris in strains of K. pneumoniae NTCC 9633 (National Collection of Type Cultures), with MIC in $40 \mathrm{mg} / \mathrm{mL}$ (van Vuuren, Suliman, \& Viljoen, 2009), similar to our findings.

In the present study, extracts of G. sylvestre, S. barbatiman, and T. vulgaris showed bacteriostatic action, with different MIC values, these results may open new paths for pioneering studies with herbal medicines, which aim to interact with different therapies using the capacity inhibitory effect of these extracts in combination with conventional antimicrobial drugs (Hong et al., 2016; Kuok et al., 2017; Olajuyigbe \& Afolayan, 2012, 2013; Silva et al., 2019).

The extracts of $H$. virginiana, J. regia, P. americana, P. paniculata, and $R$. officinalis showed better antimicrobial results, with microbicidal concentrations (MMC) for all tested strains. The broth microdilution test indicated $50 \mathrm{mg} / \mathrm{mL} \mathrm{MMC}$ for glycolic extract of $H$. virginiana in strains KPC 367725, 400381 and ATCC 4352, with replications of biofilm ranging from $41 \%$ to $47 \%$. Despite being considered antiseptic; few studies have evaluated the antimicrobial action of $H$. virginiana. Mouchrek et al. (2015) evaluated the anti-biofilm action of several commercial types of mouthwash and, among the tested substances, $H$. 
virginiana demonstrated a reduction in dental biofilm, however, only the clinical aspect of biofilms was evaluated, that is, there was no identification of microbial species that suffered reductions (Mouchrek Junior et al., 2015).

Pereira et al. (2008) found that two different aqueous extracts of J. regia showed antimicrobial action against clinical isolates of K. pneumoniae from urinary infections with MIC values of $100 \mathrm{mg} / \mathrm{mL}$ (J. Pereira et al., 2008), corroborating the results obtained in the present study for strains KPC 367725 and ATCC 4352, except for the fact that, in our study, the glycolic extract was used. Rather et al. (2012) evaluated the action of J. regia essential oil in K. pneumoniae strains, using the agar diffusion technique and the verified antimicrobial action (Rather et al., 2012). Regarding the action of antibiofilm, De Paula Ramos et al. (2016) evaluated the potential of the glycolic extract of J. regia in the ATCC strain of K. pneumoniae (4352) and found that the biomass reduction was not statistically significant ( $\mathrm{p}<0.05)$ compared to the control group (Paula-Ramos et al., 2016), confirming the results of this study. The present study also demonstrates that the clinical strain 400381 was sensitive to the action of the extract of J. regia, with reductions of 33.8 and $39.7 \%$ of the biofilm, showing a strong potential for the use of antimicrobials in these resistant multi-drug strains, with promising results.

Few studies have evaluated the action of P. americana extract on strains of K. pneumoniae. Idris et al. (2009) found that extracts of $P$. americana based on petroleum ether, ethyl acetate, chloroform and methanol obtained similar MIC values against clinical strains of $K$. pneumoniae, with growth inhibition at a concentration of $30 \mathrm{mg} / \mathrm{mL}$ (Idris, S, GI, \& CE, 2009). In the present study, it was possible to observe the microbicidal activity of the extract of $P$. americana against all strains of $K$. pneumoniae.

Although studies on the anti-inflammatory role of P. paniculate are common (Costa et al., 2015; da Silva et al., 2015), studies on its antimicrobial activity are rare. In the present study, it was found that the glycolic extract of $P$. paniculata has an important antimicrobial action in resistant multidrug clinical strains of $K$. pneumoniae, corroborating with De Paula Ramos et al. (2016), who evaluated a clinical strain (Paula-Ramos et al., 2016). It can be seen that the sensitivity to the extract varies according to the strain, with MIC and MMC values ranging from 12.5 to $25 \mathrm{mg} / \mathrm{mL}$ (Paula-Ramos et al., 2016) and from 50 to $100 \mathrm{mg} / \mathrm{mL}$ in the present study. The results found in the biofilm tests follow the same direction as those found by De Paula Ramos (2016), who indicated reductions in biomass and metabolic activity of 55.7 and $72.3 \%$, respectively, with the use of the extract. P. paniculata at $200 \mathrm{mg} / \mathrm{mL}$ in strain ATCC 4352 (Paula-Ramos et al., 2016). In the present study, lower concentrations of the extract were applied, 25 and $50 \mathrm{mg} / \mathrm{mL}$, with reductions of 35.9 and $37.7 \%$ for biomass and 42.7 and $50 \%$ for metabolic activity, respectively.

Prabuseenivasan et al. (2006) used the essential oil of R. officinalis and the indicated antimicrobial action of the herb. By testing the zone of inhibition, they found a $27.5 \mathrm{~mm}$ zone of inhibition for the growth of the ATCC 15380 strain of $K$. pneumoniae, indicating its high sensitivity. These authors also indicated that even using an ATCC strain of $K$. pneumoniae, few extracts obtained antimicrobial activity, only 9 of the 21 extracts tested showed positive results (Prabuseenivasan, Jayakumar, \& Ignacimuthu, 2006). The question of $K$. pneumoniae resistance can also be seen in the present study, since 3 of the 8 extracts tested did not have great antimicrobial potential. However, it is important to emphasize that 5 extracts showed a promising antimicrobial potential, even when applied to biofilms of strains resistant to conventional antibiotics. These results corroborate the development of new antimicrobial drugs, in addition to pointing out new directions for research involving the active principles of the extracts under study.

\section{Conclusion}

In conclusion, the glycolic extracts of H. virginiana, J. regia, P. americana, P. paniculata and R. officinalis showed antimicrobial action, resulting in concentrations with microbicidal capacity and reductions in the K. pneumoniae MDR biofilms. 
The extracts of G. sylvestre, S. barbatiman, and T. vulgaris, despite not presenting microbicidal concentrations, provided inhibitory concentrations in resistant strains of $K$. pneumoniae, which can be explored as adjuvant therapy with the use of antibiotics. In addition to the antimicrobial action on planktonic strains, the extracts also demonstrated anti-biofilm action. Among the extracts studied, those that were most effective in the anti-biofilm action were J. regia, P. paniculata and $R$. officinalis, promoting significant reductions in biomass and metabolic activity. In view of this, our findings revealed that these extracts investigated have antimicrobial and anti-biofilm activity, and may be a promising therapeutic alternative for $K$. pneumoniae MDR

\section{Declarations}

Ethical Statement: Clinical isolates of K. pneumoniae were obtained from a hospital in São José dos Campos, São Paulo, Brazil, where the samples are collected directly from the patient. We asked the hospital staff for permission to obtain access to laboratory strains, being cautious about all the ethical and legal precepts that govern this type of subject, where after hospital approval, we obtained access only the samples already collected and analyzed from micro-organisms that belong to the sample repertoire of the laboratory, not getting direct contact with the patient, due to this the approval of the ethics committee is not applied.

Funding: This work was supported by the:

Fundação de Amparo à Pesquisa do Estado de São Paulo (FAPESP) [FAPESP scholarship: 15/08776-3]

Conselho Nacional de Desenvolvimento Científico e Tecnológico (CNPq): 307396/2018-5

\section{References}

Arora, D. S., \& Sood, H. (2017). In vitro antimicrobial potential of extracts and phytoconstituents from Gymnema sylvestre R.Br. leaves and their biosafety evaluation. AMB Express, 7(1), 115. doi:10.1186/s13568-017-0416-z

Aslam, B., Wang, W., Arshad, M. I., Khurshid, M., Muzammil, S., Rasool, M. H., \& Baloch, Z. (2018). Antibiotic resistance: a rundown of a global crisis. Infect Drug Resist, 11, 1645-1658. doi:10.2147/IDR.S173867

Assis, F. V., Siqueira, F. L., Gonçalves, I. E., Lacerda, R. P., Nascimento, R. A., Araújo, S. G., \& Ferreira, J. M. S. (2018). Antibacterial activity of Lamiaceae plant extracts in clinical isolates of multidrug-resistant bacteria. An Acad Bras Cienc, 90(2), 1665-1670. doi:10.1590/0001-3765201820160870

Bowers, J. R., Lemmer, D., Sahl, J. W., Pearson, T., Driebe, E. M., Wojack, B., \& Keim, P. (2016). KlebSeq, a Diagnostic Tool for Surveillance, Detection, and Monitoring of Klebsiella pneumoniae. J Clin Microbiol, 54(10), 2582-2596. doi:10.1128/JCM.00927-16

Cai, J. C., Yang, W., Hu, Y. Y., Zhang, R., Zhou, H. W., \& Chen, G. X. (2012). Detection of KPC-2 and qnrS1 in clinical isolates of Morganella morganii from China. Diagn Microbiol Infect Dis, 73(2), 207-209. doi:10.1016/j.diagmicrobio.2012.03.013

Clegg, S., \& Murphy, C. N. (2016). Epidemiology and Virulence of Klebsiella pneumoniae. Microbiol Spectr, 4(1). doi:10.1128/microbiolspec.UTI-0005-2012

Costa, C. A., Tanimoto, A., Quaglio, A. E., Almeida, L. D., Severi, J. A., \& Di Stasi, L. C. (2015). Anti-inflammatory effects of Brazilian ginseng (Pfaffia paniculata) on TNBS-induced intestinal inflammation: Experimental evidence. Int Immunopharmacol, 28(1), 459-469. doi:10.1016/j.intimp.2015.07.002

da Silva, T. C., Cogliati, B., Latorre, A. O., Akisue, G., Nagamine, M. K., Haraguchi, M., \& Dagli, M. L. (2015). Pfaffosidic Fraction from Hebanthe paniculata Induces Cell Cycle Arrest and Caspase-3-Induced Apoptosis in HepG2 Cells. Evid Based Complement Alternat Med, 2015, 835796. doi:10.1155/2015/835796

de Freitas, A. L. D., Kaplum, V., Rossi, D. C. P., da Silva, L. B. R., Melhem, M. S. C., Taborda, C. P., \& Ishida, K. (2018). Proanthocyanidin polymeric tannins from Stryphnodendron adstringens are effective against Candida spp. isolates and for vaginal candidiasis treatment. J Ethnopharmacol, 216, 184-190. doi:10.1016/j.jep.2018.01.008

de Oliveira, J. R., de Jesus, D., Figueira, L. W., de Oliveira, F. E., Pacheco Soares, C., Camargo, S. E., \& de Oliveira, L. D. (2017). Biological activities of Rosmarinus officinalis L. (rosemary) extract as analyzed in microorganisms and cells. Exp Biol Med (Maywood), 242(6), 625-634. doi:10.1177/1535370216688571

De Zoysa, M. H. N., Rathnayake, H., Hewawasam, R. P., \& Wijayaratne, W. M. D. G. (2019). Determination of. Int J Microbiol, 2019 , 7431439. doi: $10.1155 / 2019 / 7431439$

Djeribi, R., Bouchloukh, W., Jouenne, T., \& Menaa, B. (2012). Characterization of bacterial biofilms formed on urinary catheters. Am J Infect Control, 40(9), 854-859. doi:10.1016/j.ajic.2011.10.009 
Elansary, H. O., Szopa, A., Kubica, P., Ekiert, H., Ali, H. M., Elshikh, M. S., \& El-Ansary, D. O. (2018). Bioactivities of Traditional Medicinal Plants in Alexandria. Evid Based Complement Alternat Med, 2018, 1463579. doi:10.1155/2018/1463579

Elisha, I. L., Botha, F. S., McGaw, L. J., \& Eloff, J. N. (2017). The antibacterial activity of extracts of nine plant species with good activity against Escherichia coli against five other bacteria and cytotoxicity of extracts. BMC Complement Altern Med, 17(1), 133. doi:10.1186/s12906-017-1645-Z

Farooqui, A., Khan, A., Borghetto, I., Kazmi, S. U., Rubino, S., \& Paglietti, B. (2015). Synergistic antimicrobial activity of Camellia sinensis and Juglans regia against multidrug-resistant bacteria. PLoS One, 10(2), e0118431. doi:10.1371/journal.pone.01184311

Fournomiti, M., Kimbaris, A., Mantzourani, I., Plessas, S., Theodoridou, I., Papaemmanouil, V., \& Alexopoulos, A. (2015). Antimicrobial activity of essential oils of cultivated oregano (Origanum vulgare), sage (Salvia officinalis), and thyme (Thymus vulgaris) against clinical isolates of Escherichia coli, Klebsiella oxytoca, and Klebsiella pneumoniae. Microb Ecol Health Dis, 26, 23289. doi:10.3402/mehd.v26.23289

Gadisa, E., Weldearegay, G., Desta, K., Tsegaye, G., Hailu, S., Jote, K., \& Takele, A. (2019). Combined antibacterial effect of essential oils from three most commonly used Ethiopian traditional medicinal plants on multidrug resistant bacteria. BMC Complement Altern Med, 19(1), 24. 10.1186/s12906-019-2429-4

Goossens, H. (2009). Antibiotic consumption and link to resistance. Clin Microbiol Infect, 15 Suppl 3, 12-15. 10.1111/j.1469-0691.2009.02725.x

Hadadi, Z., Nematzadeh, G. A., \& Ghahari, S. (2020). A study on the antioxidant and antimicrobial activities in the chloroformic and methanolic extracts of 6 important medicinal plants collected from North of Iran. BMC Chem, 14(1), 33. 10.1186/s13065-020-00683-5

Hong, S. B., Rhee, M. H., Yun, B. S., Lim, Y. H., Song, H. G., \& Shin, K. S. (2016). Synergistic Anti-bacterial Effects of Phellinus baumii Ethyl Acetate Extracts and $\beta$-Lactam Antimicrobial Agents Against Methicillin-Resistant Staphylococcus aureus. Ann Lab Med, 36(2), 111-116. 10.3343/alm.2016.36.2.111

Idris, S, GI, N., \& CE, G. (2009). Preliminary phytochemical screening and antimicrobial activity of seed extracts of Persea americana (Avocado Pear). In (Vol. 2): Bayero Journal of Pure and Applied Sciences.

Ishida, K., Rozental, S., de Mello, J. C., \& Nakamura, C. V. (2009). Activity of tannins from Stryphnodendron adstringens on Cryptococcus neoformans: effects on growth, capsule size and pigmentation. Ann Clin Microbiol Antimicrob, 8, 29. 10.1186/1476-0711-8-29

Khalil, N., Fikry, S., \& Salama, O. (2020). Bactericidal activity of Myrrh extracts and two dosage forms against standard bacterial strains and multidrug-resistant clinical isolates with GC/MS profiling. AMB Express, 10(1), 21. 10.1186/s13568-020-0958-3

Kuok, C. F., Hoi, S. O., Hoi, C. F., Chan, C. H., Fong, I. H., Ngok, C. K., \& Fong, P. (2017). Synergistic antibacterial effects of herbal extracts and antibiotics on methicillin-resistant Staphylococcus aureus: A computational and experimental study. Exp Biol Med (Maywood), 242(7), 731-743. doi: $10.1177 / 1535370216689828$

Li, B., \& Webster, T. J. (2018). Bacteria antibiotic resistance: New challenges and opportunities for implant-associated orthopedic infections. J Orthop Res, 36(1), 22-32. doi:10.1002/jor.23656

Mouchrek Junior, J. C., Nunes, L. H., Arruda, C. S., Rizzi, C. e. C., Mouchrek, A. Q., Tavarez, R. R., \& Maia Filho, E. M. (2015). Effectiveness of Oral Antiseptics on Tooth Biofilm: A Study in vivo. J Contemp Dent Pract, 16(8), 674-678. doi:10.5005/jp-journals-10024-1739

Olajuyigbe, O. O., \& Afolayan, A. J. (2012). Synergistic interactions of methanolic extract of Acacia mearnsii De Wild. with antibiotics against bacteria of clinical relevance. Int J Mol Sci, 13(7), 8915-8932. doi:10.3390/ijms13078915

Olajuyigbe, O. O., \& Afolayan, A. J. (2013). Evaluation of combination effects of ethanolic extract of Ziziphus mucronata Willd. subsp. mucronata Willd. and antibiotics against clinically important bacteria. ScientificWorldJournal, 2013, 769594. doi:10.1155/2013/769594

Osman, K. M., Hassan, H. M., Orabi, A., \& Abdelhafez, A. S. (2014). Phenotypic, antimicrobial susceptibility profile and virulence factors of Klebsiella pneumoniae isolated from buffalo and cow mastitic milk. Pathog Glob Health, 108(4), 191-199. doi:10.1179/2047773214Y.0000000141

Pacios, O., Blasco, L., Bleriot, I., Fernandez-Garcia, L., González Bardanca, M., Ambroa, A., \& Tomás, M. (2020). Strategies to Combat Multidrug-Resistant and Persistent Infectious Diseases. Antibiotics (Basel), 9(2). doi:10.3390/antibiotics9020065

Paula-Ramos, L., da Rocha Santos, C. E., Camargo Reis Mello, D., Nishiama Theodoro, L., De Oliveira, F. E., Back Brito, G. N., \& de Oliveira, L. D. (2016). Planktonic and Biofilm Reduction by Different Plant Extracts:. ScientificWorldJournal, 2016, 3521413. doi:10.1155/2016/3521413

Pereira, E. M., Gomes, R. T., Freire, N. R., Aguiar, E. G., Brandão, M., \& Santos, V. R. (2011). In vitro antimicrobial activity of Brazilian medicinal plant extracts against pathogenic microorganisms of interest to dentistry. Planta Med, 77(4), 401-404. doi:10.1055/s-0030-1250354

Pereira, J., Oliveira, I., Sousa, A., Ferreira, I., Bento, A., \& Estevinho, L. (2008). Bioactive properties and chemical composition of six walnut (Juglans regia L.) cultivars. Food and chemical toxicology : an international journal published for the British Industrial Biological Research Association, 46, 2103-2111. doi:10.1016/j.fct.2008.02.002

Prabuseenivasan, S., Jayakumar, M., \& Ignacimuthu, S. (2006). In vitro antibacterial activity of some plant essential oils. BMC Complement Altern Med, 6, 39. doi:10.1186/1472-6882-6-39

Rahim, K., Qasim, M., Rahman, H., Khan, T. A., Ahmad, I., Khan, N., \& Saleha, S. (2016). Antimicrobial resistance among aerobic biofilm producing bacteria isolated from chronic wounds in the tertiary care hospitals of Peshawar, Pakistan. J Wound Care, 25(8), 480-486. doi:10.12968/jowc.2016.25.8.480

Ramstedt, M., Ribeiro, I. A. C., Bujdakova, H., Mergulhão, F. J. M., Jordao, L., Thomsen, P., \& Sjollema, J. (2019). Evaluating Efficacy of Antimicrobial and Antifouling Materials for Urinary Tract Medical Devices: Challenges and Recommendations. Macromol Biosci, 19(5), e1800384. doi:10.1002/mabi.201800384

Rather, M. A., Dar, B. A., Dar, M. Y., Wani, B. A., Shah, W. A., Bhat, B. A., \& Qurishi, M. A. (2012). Chemical composition, antioxidant and antibacterial activities of the leaf essential oil of Juglans regia L. and its constituents. Phytomedicine, 19(13), 1185-1190. doi:10.1016/j.phymed.2012.07.018 
Research, Society and Development, v. 10, n. 12, e240101220270, 2021

(CC BY 4.0) | ISSN 2525-3409 | DOI: http://dx.doi.org/10.33448/rsd-v10i12.20270

Roca, I., Akova, M., Baquero, F., Carlet, J., Cavaleri, M., Coenen, S., \& Vila, J. (2015). The global threat of antimicrobial resistance: science for intervention. New Microbes New Infect, 6, 22-29. doi:10.1016/j.nmni.2015.02.007

Selvi, S., Devi, P. U., Chinnaswamy, P., Giji, T. M., \& Sharmila, S. P. (2007). Antibacterial efficacy and phytochemical observation of some Indian medicinal plants. Anc Sci Life, 26(3), 16-22.

Silva, D. M., Costa, P. A. D., Ribon, A. O. B., Purgato, G. A., Gaspar, D. M., \& Diaz, M. A. N. (2019). Plant Extracts Display Synergism with Different Classes of Antibiotics. An Acad Bras Cienc, 91(2), e20180117. doi:10.1590/0001-3765201920180117

van Vuuren, S. F., Suliman, S., \& Viljoen, A. M. (2009). The antimicrobial activity of four commercial essential oils in combination with conventional antimicrobials. Lett Appl Microbiol, 48(4), 440-446. doi:10.1111/j.1472-765X.2008.02548.x

Vuotto, C., Longo, F., Balice, M. P., Donelli, G., \& Varaldo, P. E. (2014). Antibiotic Resistance Related to Biofilm Formation in Klebsiella pneumoniae. Pathogens, 3(3), 743-758. doi:10.3390/pathogens3030743

WHO. (2017). WHO publishes list of bacteria for which new antibiotics are urgently needed. In. World Health Organization. 